\title{
Sustainability Issues in River Tourism: A Case Study of Ganges in Varanasi
}

\author{
Neha Tandon *
}

\section{Abstract}

Understanding future expectations and fulfilling current demands with a view of conserving social, cultural and natural environment of a destination, can be referred to as sustainable tourism. Changes in social and cultural environment are identified a little early than their natural counterpart. The first two being more vocal and narrates quick reactions among its audiences. Changes in natural environment lie silent till the time they reach a visible level of depletion. The present paper will highlight sustainability issues in river tourism, which is one of the significant natural resources for tourism. Understanding the dependency of tourism on rivers and highlighting its positive and negative effects of it, will be discussed in the paper. The paper is supported by a case study on 'The Ganges in Varanasi'. The Holy Ganges is the lifeline of the city and is facing immense sustainability issues, which has raised questions against her future existence. The problems faced and measures taken by various organizations, government bodies, and individuals to protect the lifeline of the oldest living city of the world will be examined further.

Keywords: Sustainable tourism; River tourism, Natural environment.

\footnotetext{
* Research and Teaching Assistant at Indira Gandhi National Open University, Block-01, SOTHSM, IGNOU, Maidan Garhi, New Delhi-68; nehazsky@gmail.com
} 


\section{Introduction}

Nature has its own tunes and rhythms to play. Interfering into the natural environment and creating irrepressible ruckus stimulates negative effects. Identifying these negative effects and measuring their level of consequences in advance is little difficult, but is not an unworkable part of the sustainability issues. The consequences faced or expected is not only experienced in the natural context but are also applicable in cultural, social, and economic dimensions of sustainable tourism. Also, the short-term, hedonistic approach by majority of the travel companies has 'improved touristic movements' but has failed to calculate the degree of its consequences. Therefore, the responsibility lies in the hands of the experts, policy makers, and government to come up with positive outcomes, while implementing sustainability measures for tourism. Today, understanding its significance, the tourism industry is taking major steps to make sustainable tourism an integral part of the industry. Its enlarged magnitude also includes niche tourism products. It may be guided by nature walk at Periyar, or adventurous trekking to the Everest base camp or the tranquil river-ride on the Ganges; each has its own beauty and story to narrate. Each of its significance, highlights the relevance of sustainability factors in tourism and supports positive, planned and holistic approach in maintaining the destinations beauty.

\section{Importance of the Study}

Since ages, the rivers have facilitated in the growth and development of various civilizations. It plays various roles in tourism as well; such as recreational activities, transportation or cruising, water for drinking, food source, support for manufacturing etc. When the above benefits are bungled, it creates a negative effect and leads to serious repercussions of the industry. Presently, there are many rivers which are fighting for its existence. One such example is of the Ganges, which is also the national river of India. It is exceptionally revered by the people within and outside the country. The river flows through many towns and cities in the country including Varanasi. Varanasi is the oldest living city of the world and the Ganges is the lifeline of its people. The river 
is the Mother goddess to its worshipers; the river also plays a significant role in helping many petty shop owners, souvenir sellers, boat-man etc., to earn their livelihood. One can visualise the scene on the Ghats of Varanasi, with meditating sadhus, pundits performing pooja, washer-man washing clothes, tourists strolling on the Ghats or just sitting idle and observing the bustle, boatman calling their prospective passengers to take the ride on the river, etc. The above lines explain well, the significance of the river among the locals and tourists. Several measures have been taken by the government and the local bodies, to reduce the contamination level of the Ganges, but all has gone in vain. To protect the river from forced depletion, it is essential to follow a planned sustainable approach. Sustainable approach such as completely banning the use of plastic bags in the city, restraining sewage flow into the river, etc needs immediate implementation. Lack of such measures has resulted in the undertaking of the below mentioned objectives.

\section{Objective of the Study}

1. To explicate the relationship between the river, tourism and sustainability.

2. To highlight the measures taken by the government, media, individuals and locals on sustainably developing river tourism in the study area.

3. To suggest further measures for the development of sustainable river tourism.

\section{Methodology}

The methodology used in the study is qualitative in nature. It is mainly based on secondary data. The data is collected from government reports, newspapers, books, and various websites. The suggestions made in the paper are based on personal experiences and observations done, while visiting the city. The observations are unpretentious and are based on frequent visits by the researcher to the city during her field work. 


\section{River Tourism and Sustainability}

Great rivers of the world have aroused interest and provided the backdrop for travellers. The scenic beauty and diversified landscapes throughout the water course creates a unique impression on the minds of the voyager. Therefore its significance was not only experienced but also written on by many great historians, like Herodotus, who described his journey to Egypt in 450 BC (Prideaux 2009; Cooper 2009). Likewise, Thomas Coryat, an English traveller, came to India and stayed here from 1612-1617 just to experience the Ganges. He made an oration in Persian at Jahangir's court, mentioning the Ganges as 'Captaine of all the rivers of the world' (Mahajan Jagmohan, The Ganga Trail, Foreign Accounts and Sketches of the river Scene). Similarly many past historians, scholars wrote their experiences and shared thoughts on river journeys. This also evoked interest among the readers and forced them to explore the well written journeys of the past. Therefore, we can say that rivers are an inseparable part of human history.

Rivers are directly related to tourism in many ways. They offer amazing natural landscape, wide range of flora and fauna and also offer a spectacle into the day to day life of the indigenous living by its side, as well as narrate its history, that draws people from distant places. Water, which is the main feature of river tourism is one of the populist natural settings for rest and recreation. Even short periods near water are claimed to have a beneficial soothing effect on most people (Frazier, 2000). Therefore destinations promoting rivers, lakes, waterfalls, hot springs, beaches and even manmade attractions featuring waters are more liked by people. This not only boosts tourism activity but also helps in earning more money for the economy.

Rivers represent beauty, serenity and ecstasy. They also act as political boundaries for regional, state and international entities and are being used as the major mode of transportation since ages. They reduce the burden of complicated navigational challenges, unlike sea or ocean journeys which are harsh and perilous. River journeys in comparison to sea journeys are less monotonous and less challenging. Lifeline for many big-small, old-new cities, rivers 
are important tourism resources of the present world. They cannot be ignored and life without them is unfeasible. Rivers, lakes, etc form the fresh water resources of the world, constituting less than $1 \%$ of the total share. Knowing the limitation of fresh water resources, is essential to come up with policies that offer longevity to its existence. Today rivers play an important role on tourism, both directly and indirectly (Prideaux 2009; Cooper 2009).

\section{Direct roles include}

- location for activities and places of tourist interest, including built and natural environments;

- transport, including cargo barges and river cruising;

- providing recreational activities (including water sports and fishing);

- supply of portable drinking water.

\section{Indirect roles include}

- food source, either directly or through the supply of fish and other food sources or indirectly through agriculture that the river supports;

- transport zone;

- support for manufacturing activities;

- disposal of human and industrial waste;

- provision of hydroelectricity.

The direct and indirect role has great importance in maintaining the sustainability factor of the rivers. Any kind of misuse or unsustainable act, will lead to a higher degree of depletion to the world's river system. Vessels, either used as cruises or simple modes of transportation, emit chemical and toxic wastes, ballast water etc. Nitrates, pesticides, heavy metals and hydrocarbons are some of the major fresh water pollutants. Since ages rivers have been used as waste water disposal facility by factories emitting toxics, which badly affect the health of the river. Also increasing population, economic development, growth in recreational activities, climatic changes, poor water resource management, has 
already affected the rivers a lot and has contributed to the weakening of water tables, poor quality and shrinking of rivers in major parts of the world. Therefore special and immediate attention is required by industry stakeholders to protect it from depletion.

\section{Case Study: The Ganges in Varanasi}

\section{Ganges}

Rivers in India covers 329 million hectares of geographical area. They have a strong cultural, historical, religious, and geographical significance. Since ages, they are personified as deities and hold great religious importance. The Ganges holds a significant value among Indians and its neighbouring countries. It originates from the Gangotri glacier in the Himalayas at an elevation of $7756 \mathrm{~m}$. Travelling $200 \mathrm{~km}$ down the Himalyas, the Ganges appears at the religious town of Haridwar. From here, it starts flowing in the south-eastern direction through the plains of Northern India. Later, covering the long stretch of $800 \mathrm{~km}$, it joins the river Yamuna at Allahabad. The confluence of Ganga and Yamuna is called Sangam, a sacred place for Hindus. About $125 \mathrm{~km}$ away from Allahabad is the eternal city of Varanasi, where the Ganga flows in the shape of a half-crescent moon. Said to be the life line of the city, the Ganga is the living goddess for the locals of Varanasi. The Ganga joins various rivers such as Kosi and Ghagra beyond Allahabad; from Bhagalpur it changes its course to southwards to meet the Brahmputra. Its lower basin has both active and inactive delta with some oxbow lakes as well.

\section{Tourism perspective of the Ganges}

Lakhs of domestic tourists visit Varanasi every year to take a holy dip in the Ganges and to wash away their sins. They are emotionally and religiously attached to the place. The number of tourists increases in the month of festivals like karthik poornima, amavasya, basant panchmi and many other days of religious importance. Apart from these, there is the usual visit by the domestic tourists, who feel that taking a holy dip in the Ganges will purify their soul and helps them to attain salvation. People also immerse the ashes of their dead relatives in the Ganges as it is believed that the soul gets released from the circle of life and death 
and reaches heaven. The city holds great importance in history as it is the oldest living city in the world.

Varanasi, also known as Kashi, the city of lights, is known for its temples, narrow lanes, ghats, food, art and craft, music, education etc. The temple city is a year round destination for both domestic and international tourists. This could be backed by the tourist trend witnessed in 2010, when the flow of foreign tourists remained high during off season as well (April-August). Foreign tourist arrivals, ten years back in 2000 was just 1,15,254, which in 2010 increased to $2,19,088$. A number of foreign tourists, also visit the city to learn music, yoga, Sanskrit, Indian art and culture etc. Then the cities combination of traditional and contemporary cuisine attracts not only domestic but foreign tourists as well. From age-old delectable delights of puri-kachori, jalebi, thandai, sweets and paan as digestives to its continental cuisine, the city has lots to offer to its visitors. Kimchi fried rice with tonkatu (Korean dish), eggplant lady finger (Israeli), yasaikakiage hot soba (Japanese) are famous dishes available at the restaurants near the Ghats. These restaurants are popular among backpackers and students of foreign origin as they offer good food along with the scenic view of the Ganges. River-rides in the morning or witnessing the sunset in the evening is equally popular among both the domestic and international tourists. The river draws more tourists in the month of winter, when migratory birds visit the city. The tourists enjoy these winged creatures gliding in the river Ganges, chirping and chasing fish for the food. The enchanting Ganga aarti in the evening, draws not only the locals but also the tourists. The city experiences great number of tourists, when all the ghats by the Ganges are decorated with earthen-lamps on the occasion of dev-deepawali. The Ghats are crowded from dawn till dusk with small vendors selling eatables, people sitting under the giant hand-made umbrellas watching the serene flow of the river, Sadhus offering prayers, with few foreigners enjoying the local massage; this showcases a different life altogether.

\section{Sustainability issues}

Nearly 1.3 billion litres of human waste, mostly untreated raw waste per day gets added to the Ganges. Putting partially burnt-un- 
burnt corpses, animal carcasses in the Ganges adds to the inadequate cremation procedure. Not only this, but throwing polythene bags containing garlands, incense sticks, pooja clothes, or non-degradable things into the river has also increased the level of its contamination. $80 \%$ by volume of the total waste is dumped into the Ganges as municipal waste. The major environmental issues associated with the Ganges includes (Prideaux 2009; Cooper 2009):

- Increasing demands on natural resource from development activities including tourism;

- The inward penetration of higher salinity levels;

- The spread of waterborne diseases due to the extensive embankment of former spread-out bodies of water;

- Water and soil pollution;

- Decline in fisheries due to human intervention; and

- The excessive felling of the Sunderbans deltaic forest.

More than 29 cities, 70 towns and thousands of villages lie on the entire stretch of the Ganges. The Ganges and its tributaries collect greater amount of human pollutants as it passes through the Northern Indian plains. Reports say that 260 million litres (15\% by volume of total waste) of industrial waste is added to the river by the factories along the river bank. Among the major industrial wastes is chromium, discharged from leather industries mainly located near Kanpur. Here the water stinks even during the flooded period of monsoons. In the lean period, the river becomes so shallow that one can walk through the black muddy waters.

Over $50 \%$ of the pollutants, entering the Ganges is from the state of Uttar Pradesh. Before GAP, 13 drains were entering the river but today almost 50 drains carry raw sewage to the Ganga and Yamuna waters. The 84 bathing Ghats between Varuna and Assi in Varanasi has today become huge sewage drains. The river is losing its sanctity due to the increased amount of raw sewage waste in it.

Though some of the busy ghats have been declared a 'plastic free zone', still a number of shopkeepers, flower and snack vendors use 
plastic bags on the demands of locals, domestic, and international tourists.

The two tributaries of Ganga in Varanasi, viz. Varuna and Asi is in a highly deplorable state. Asi has great mythological importance, as its references are found in many early literatures, such as Matsypuran, Kurma puran, Padma puran and Kashi Khand. Asi had a silent death with its onlookers, just, watching the transmutation of the fresh water into sewage and wastewater drains. Varuna is today on the verge of dying. It originates from Phulpur in Allahabad and meets Ganges at Sarai Mohana. Varanasi is situated between Varuna and Asi which gave the city its name . The day will not be too far when the depletion of Varuna will become the major reason for the depletion of the Ganges.

The Ganges' unusual trend has drawn the attention of the environmentalists. Last year, nearby areas of the river in the city got flooded five times in a single season. Over 400 shops and make-shift stores with around 300 boatmen got badly affected due to the unusual flowing pattern of the Ganges. They had to sit at home, for they could not open their shops, as it was half submerged. Boatmen offer their boats as a seating place in return of some money from the tourists who came to view the Ganga Aarti at Dasaswamedh Ghat in the evening. Food vendors and kids selling earthen lamps to tourists/visitors had to wait or opted for guiding as a temporary job.

The decrease in water level will automatically result in the decrease of oxygen content. This will together affect the aquatic life and environment. The repercussions of such things can be so strong, that we may soon lose the perennial nature of the river. With over 140 species of fishes, 90 species of amphibians and five such areas, which supports birds found nowhere in the world, the river is at risk today. The World Wildlife Fund has rated Ganga as one of the world's top ten rivers at risk

\section{Efforts Made by Various Bodies}

\section{Government}

For immediate reduction of pollution load on the Ganges, the Ganga Action Plan was approved by the government in 1985 and 
launched by the late Prime Minister Rajiv Gandhi in 1986. The main aim of the plan was to build a number of waste management facilities in collaboration with a number of voluntary organizations. More than 250 wastewater treatment plants have been completed under the scheme, but till date sewage continues to flow unabated into the Ganges and its tributaries. The existing plants face difficulties of faulty engineering, intermittent electricity supplies and maintenance problems. This plan, though introduced with great hope has showed very less results as of now. In February, 1985, in order to oversee the implementation of GAP and to lay its policies and programmes, the Government of India constituted the Central Ganga Authority under the chairmanship of the Prime Minister. This was renamed as the National River Conservation Authority in September 1995. In June 1985, the Ganga Project Directorate was established as a wing of the Department of Environment. It aimed at executing projects under the guidance and supervision of CGA. This also got renamed in June 1994, as National River Conservation Directorate. So far, only 39\% of the primary target of the Ganga action plan has been met. Till date a number of measures has been taken by the government, which has not been effective.

In 1989, the late Prime Minister Rajiv Gandhi took initiatives, to make tortoise sanctuary between Rajghat to Ramnagar to protect the Ganges from pollution. Every year, around 3000 tortoises are put in this area to maintain the cleanliness of the river. These tortoises can easily consume garland, flowers, corpses which are put into the river due to the religious practices. Engine driven boats are restricted in this area to protect the life of these tortoises. Sand excavation, constructing new buildings and other related work that can hamper their existence is strictly prohibited in the area. Kashi Vanyajeev has also asked for fresh budget to get advanced cameras to watch these tortoises from the muddy water as well.

The report prepared by the consortium of seven IIT's about the Ganga River Basin Management Plan (GRBMP) does not satisfy the experts of National Ganga River Basin Authority. NGRBA was constituted by the government on February 20, 2009 under the environment protection act 1986, for the cleaning of river. 
A project initiated a year ago by the Tourism department for renovating and beautifying one of the seven Ghats of Varanasi has produced no results till date. The project was worth Rs. 7.86 crore. Renovation and upgradation of ten sacred Kunds and fourteen prominent gullies leading to the ghats, were also part of this project. The present conditions of the ghats, narrates the truth and still shows un-plastered walls, broken slabs, exposed iron grills, uprooted stone slabs, etc.

The Central Pollution Control Board (CPCB) has got the direct powers of issuing closure notices to industries polluting Ganges in Uttar Pradesh. In the last two decades almost Rs 900 crores has been spent on the Ganga Action Plan.

\section{Media}

A report on Ganges in the Varanasi edition of the Times of India highlights the decreasing water level of the Ganges. The increasing sand bed on the opposite bank of the river and stream shifting from the major Ghats has raised tension among the environmentalists as well as among the locals of Varanasi. The decreasing level of water is calculated by the measuring scale marked on the Rajghat Bridge. The problem arises when the is Ganga reduced down to the minimum level of the marked water scale. This decline has become a regular feature of the past few years. The Ganga water keeper alliance report refers to the Central water commission's report, which states that the water of Ganga has shown a regular decline in the various districts of Uttar Pradesh. These areas include Varanasi, Allahabad, Ghazipur, Mirzapur, Kannuaj and the rural areas of Kanpur. The water has been lowered by $3.22 \mathrm{~m}$ to $14.77 \mathrm{~m}$. The reduction in the flow of the river water is mainly because of pollution and siltation as per B. D. Tripathi. B. D. Tripathi, a member of the National Ganga River Basin Authority and coordinator of the Centre for Environmental Science and Technology, B. H. U, further added that heavy extraction of river water for various usages has also resulted in reduced flow. He suggested that for all the rivers, it is advisable to recharge the groundwater, retain the rainwater on the surface and minimise our water consumption. It was said that sufficient water in the rivers will solve $60-80 \%$ of river problems. Even the shrinking width of 
the Ganga was a great cause of concern, as per UK Chowdhary, professor of civil engineering and coordinator of Ganga Research Laboratory, Institute of Technology, B. H. U. Sand bed of the river is increasing by $5-6$ metre in width $8-10 \mathrm{~cm}$ in height annually.

\section{Individuals}

Vir Bhadra Mishra is the founding president of Sankat Mochan Foundation and an active dignitary who is involved in the protection of the Ganges since his early ages. He shared the idea of non-electrical interception using gravity force that restricts the flowing sewage water into the Ganges and further can be cleaned by using natural system (pond system), which was successfully used in California. His ideas attracted the PM's attention and Dr. Manmohan Singh invited him to New Delhi to give his presentation in 2007. On the account of its basic principles, this idea got accepted and was started as a pilot project. But increasing government intervention at the later stage restricted the smooth running of the project. Presently 32 places are identified as the point of flow of sewage water to Ganga. Jal Nigam, a government body believed this project to be too expensive; this is the reason behind the delay of this project. (Dainik Jagran, 2011)

G. D. Agrawal, 80, is a former head of the Department of Civil and Environmental Engineering at the Indian Institute of Technology in Kanpur, and is a past secretary of the Indian government's Central Pollution Control Board. He is known to his followers as Swami Gyan Swarup Sanand who fasted for more than a month to ensure a pollution free Ganges. Still, he is incessantly fighting for the cause.

\section{Locals}

The locals turned whistleblowers on Earth Day. With handmade cotton bags in hands and blowing whistles, they not only collected wastes thrown along the bank and in the river in bags but also warned other people present there not to pollute the Ganga by blowing whistles.

In 2010, in the month of February, the residents of Varanasi organised a mini-marathon, in order to create mass awareness about the 'Save-Ganga' campaign. Young men and women not only 
participated in this marathon but also urged masses to adopt effective methods of cleaning the Ganges.

\section{Recommendations}

The above given points are few examples which highlight the efforts made by the government, local bodies, experts, locals, etc. Some suggestions which mainly involve locals or a combination of both government and locals of the city will help in fighting this critical situation.

The main responsibility lies with the people who are from these cities, from where the holy river flows. This may look difficult but not impossible. Small steps by the locals can help in saving the existence of the river. Banning of plastic bags by all the local shops around the Ganges, with locals taking responsibility of restraining tourists or devotees who throw plastic bags, empty water bottles, cans, wrappers into the river can be practiced.

Boards displaying general rules related to the cleanliness of the river should be placed at the major Ghats and at regular intervals on the Ghats. People polluting the Ghats and the Ganges should be fined and locals can play as whistle- blowers in the protection of the area.

It is important to understand that the present situation of the Ganges is primarily due to negligence of the people and the local authority of the city. We cannot blame others for its condition. It is therefore important that Municipal bodies should work on diverting the flow of sewage that falls into the Ganges. Meanwhile, locals can do their bit and help in maintaining the cleanliness of the river. People living on the Ghats of the Ganges can be given the responsibility of supervising the cleanliness of the Ghats, falling in their areas.

The college and school students can be encouraged to perform a play/skit on subjects like pollution free river with Ganges in the backdrop. This will entertain and educate locals and tourists at the same time. Similar steps were taken by the students of tourism from BHU, when they organised a play on the ghats of Ganges on the occasion of World Tourism Day. 
The boatmen should realize that their very existence is directly dependent on the existence of the river. If the river loses its sheen and continues to deplete, the day is not far when they will have to search for another occupation. Educate the boatmen and make them aware of the damage caused because of the increasing pollution in the river.

Tourists visiting the city are equally aware of the present situation but lack motivation to conserve. Domestic tourists are religiously inclined towards the river, but most of them fail to understand the serious damage that is caused, when pooja items are put into the holy river. The turning of the Gangajal into a murky colour due to pollution has raised concerns only among a few. International tourists comparatively are more aware and counter even locals for contaminating the river. Therefore, efforts should be made to educate tourists on their significant role in reducing the contamination level of the river.

\section{Conclusion}

The Ganges has the most populous river basin in the world with more than 400 million people living in its $7,500,00 \mathrm{~km}^{2}$ area . the Ganga water is rich in medicinal qualities and also has the maximum quantity of dissolved oxygen compared to the other rivers in the world. Knowing its historical and religious significance and highlighting its scientific qualities, the Ganges still faces the problem of contamination. By giving the status of the country's first national river to the Ganges, will not solve the problem. The problem can be solved only by removing the disease from its root, rather than just listing the river under various prominent heads. Serious and combined efforts are immediately needed to protect the mother river of the country.

\section{References}

25 years of GAP \& Ganga still in despair (2011, June 14). Times of India. Retrieved from http://articles.timesofindia.indiatimes.com/2011-0614/varanasi/29656335_1_ngrba-ganga-action-plan-ganga-dussehra

Celebrating Ganga when its offsprings lose existence? (2011, June 10). Times of India. Retrieved from http:// articles.timesofindia. 
indiatimes.com/2011-06-10/varanasi/２9642536_1_varuna-and-asiganga-dussehra-asi-ghat

Foreign tourists' arrival breach 2L mark (2011, February 02) Times of India. Retrieved from http://articles.timesofindia.indiatimes.com/2011-0202/varanasi/28363436_1_foreign-tourists-tourism-officials-arrival

Ganga Mahotsav. Retrieved from http://www.gangamahotsav.org/ objective.html

Ganga pollution: Regulator gets more teeth. Thaindian News. Retrieved from http://www.thaindian.com/newsportal/enviornment/gangapollution-regulator-gets-more-teeth_100421228.html

Ganga's unusual pattern worries locals. The Times of India. Retrieved from http:/ / timesofindia.indiatimes.com/city/varanasi/Gangas-unusualpattern-worries-locals/articleshow/9964130.cms

Govt banks on utsav to infuse life in dying Ganga. Times of India. Retrieved from http://articles.timesofindia.indiatimes.com/2011-0605/lucknow/29622887_1_ganga-river-utsav-ganga-banks

Holy city condemns Oz radio host for anti-Ganga remarks (2011, August 02) Times of India. Retrieved from http:// articles.timesofindia.indiatimes.com/2011-08-

02/varanasi/29841665_1_ganga-mahasabha-anti-ganga-b-d-tripathi

Mahajan Jagmohan, The Ganga Trail, Foreign Accounts and Sketches of the river Scene. Oxygen levels in River Ganges dip alarmingly. Thaindian News. Retrieved from http://www.thaindian.com/ newsportal /india-news/oxygen-levels-in-river-ganges-dipalarmingly_10034802.html

People offer special prayers after River Ganges is declared National River. Thaindian News. Retrieved from http://www.thaindian.com/ newsportal/india-news/ people-offer-special-prayers-after-riverganges-is-declared-national-river_100117323.html

Plan overlooks many vital issues related to Ganga (2011, June 04). Times of India. Retrieved from http://articles.timesofindia.indiatimes.com/ 2011-06-04/varanasi/29620347_1_ngrba-biological-methodologiesganga-river-basin

Renovated Ghats turn ugly within a year (2011, June 01). Times of India. Retrieved from http://articles.timesofindia.indiatimes.com/2011-0601/varanasi/29607908_1_ghats-beautification-manikarnika 
Residents turn "whistleblowers" to save Ganga (2012, April 22). Times Of India. Retrieved from http://articles.timesofindia.indiatimes.com/ 2012-04-22/varanasi/31381845_1_ganga-blow-whistle-ghats

Save Ganga Movement. Retrieved from http://www. savegangamovement.org/index.php?option=com__ content\&task $=$ view\&id $=65 \&$ Itemid $=87$

Save Ganges campaign in Varanasi. Thaindian News. Retrieved from http://www.thaindian.com/newsportal/india-news/save-gangescampaign-in-varanasi-2_100312832.html

Shrinking Ganga sets alarm bells ringing (2011, June 01). Times of India. Retrieved from http://articles.timesofindia.indiatimes.com/2011-0601/varanasi/29607654_1_water-level-ngrba-uk-chowdhary

The Times of India on Mobile. Retrieved from http:// m.timesofindia.com/PDATOI/articleshow/9948259.cms

Tranquil boatride on stinking waters? (2011, June 13) Times of India. Retrieved from http://articles.timesofindia.indiatimes.com/2011-0613/varanasi/29652628_1_river-water-varuna-ngrba 